\title{
Analysis and Suggestions for Standards and Guidelines of Green Campus's Construction
}

\author{
M.Y.Lu', a J.T. Weng ${ }^{1, b^{*}}$, Y.T. Ma ${ }^{1, c}$ \\ ${ }^{1}$ Room 506, Crescent Building, Zijingang Campus of Zhejiang University, Xihu District, Hangzhou \\ City, Zhejiang Province, China \\ a709953403@qq.com, b815895960@qq.com, ${ }^{\text {c4 } 412617504 @ q q . c o m ~}$
}

\section{Keywords: Green Campus; Standards; Guidelines}

Abstract: Based on the characteristics of development of green campus construction in China, firstly the standards and guidelines green campus's construction made by the central and local government were introduced. The existing problems in the current standards and guidelines are pointed out through the contrast of different standards and guidelines. Furtherly, the corresponding improvement suggestions are put forward based on the analysis of the reason.

\section{Introduction}

In recent years with a gradually serious problem of the global environmental pollution and energy shortages, the work of energy saving and emission reduction has be more urgent. Universities, as the home of teaching, should assume more responsibilities in social development, especially in the sustainable development. Build an environment-friendly green campus and merge the concept of sustainable development between university education, students training, public service and other aspects, which has a promotable and direct meaning for the construction of university and the sustainable development of the society [1-2].

Green campus indicates a campus developing campus construction, management, scientific research and sustainable talent cultivation based on the thought of sustainable development. Generally, the foreign colleges and universities emphasize improving energy utilization efficiency, reducing greenhouse gas emission, advocating proper diet structure, low-carbon trip mode and resource recycle, etc[3]. The characteristic of green campus construction is remarkable because of the difference of region and colleges and universities.

(1) "top-down" construction mode; different from the "down-to" development mode, the green campus construction in China is mainly dominated by the government. The government makes relevant standards and guide rules while the lower organizations mainly cooperate and implement them. (2) Different importance of campus construction; because of the difference in regions and school, some colleges and universities are focused on improving the management level, some use advantages to specialize in technical research and some emphasize green idea, which are flourished[4]. (3) Development from early resource-saving campus to green campus construction; the campus construction develops from the construction of infrastructure to green conception cultivation and green behavior.

Because the campus construction observes the "top-down" mode, the main driving force of the development is from the guidance of government. The national and regional standards and guide rules directly decide the development direction of green campus construction. Therefore, it is of guiding significance to the sustainable development of campus construction in China to make reasonable and deep construction standards.

\section{Current Situation of Relevant National Standards and Guidelines}

\section{Relevant National Standards and Guidelines}

Green buildings are core to construct the green campus, and therefore the code of building design is also the part of campus construction standards and guidelines. As a result, the national standards and 
guidelines is divided into two parts: design code of campus building and guide rule of campus construction in this research. However, the green campus planning and green building design standard have not been made yet in China. (1) Design code of green campus building; the energy-saving planning and building design mainly refer to the existing energy-saving design standards and codes. Therefore, the special technical measures specific to the campus construction is lack. (2) Guide rule of green campus; the technical guidelines in the aspect of campus energy-saving monitoring system construction, energy-consumption statistical auditing, energy-consumption quota, resource-saving campus and green campus has been made since 2007. For the detailed technical documents, please refer to Table 1 below. For the construction of green campus in China, multiple standards in the aspect of construction, operation and evaluation has been made initially.

Table.1. technical guidelines of green campus's construction

\begin{tabular}{|c|c|c|}
\hline Main content & Name of technical file & Effect \\
\hline $\begin{array}{l}\text { Guidelines of } \\
\text { conservation-minded } \\
\text { campus construction }\end{array}$ & $\begin{array}{l}\text { Construction management and technical guidance of a conservation-minded } \\
\text { campus construction(trial) "jianke [2008] no. } 2008 \\
\text { Construction technical guidelines of campus building energy efficiency } \\
\text { supervision system (2009) } \\
\text { Supervision system technical guideline of operation and management of } \\
\text { colleges and universities campus building energy efficiency ( } 2009 \text { ) } \\
\text { Energy-saving operation measures for the administration of institutions of } \\
\text { colleges and universities campus facilities》 ( } 2009 \text { ) } \\
\text { Acceptance management method conservation-minded campus energy } \\
\text { regulatory system construction demonstration project "(draft) ( 2014) }\end{array}$ & $\begin{array}{l}210 \text { universities have } \\
\text { completed the } \\
\text { construction, } 50 \\
\text { universities have passed } \\
\text { the acceptance }\end{array}$ \\
\hline $\begin{array}{l}\text { Guidelines of energy } \\
\text { consumption statistics, } \\
\text { audit and energy } \\
\text { consumption quota }\end{array}$ & $\begin{array}{l}\text { Statistical measures for colleges and universities campus building energy } \\
\text { consumption ( } 2009 \text { ) }\end{array}$ & Execution effect is poor \\
\hline $\begin{array}{l}\text { Evaluation guideline of } \\
\text { conservation-minded } \\
\text { campus }\end{array}$ & $\begin{array}{l}\text { Evaluation index system and method of a conservation-minded campus } \\
\text { Standard of green campus evaluation csusgbc } 04-2013\end{array}$ & $\begin{array}{l}\text { There is no promotion is } \\
\text { carried out }\end{array}$ \\
\hline
\end{tabular}

\section{Relevant Local Standards and Guidelines}

Relative to the relevant technical guidelines and standards, the resource-saving campus has been constructed by local government based on the national standards as well as the local development characteristics and requirements. Thus the suitable regional technical guidelines are relatively lack. Through statistics and arrangement, about seven provinces and cities make corresponding technical guidelines in the aspects of proper energy-using guidance, assessment measures for the construction of colleges and universities, energy auditing technology and campus energy-saving monitoring system to guide local colleges and universities to make resource-saving campus construction specifically. For the detailed classification, please refer to Table 2.

(1) Proper energy-saving guide: it is hard to make contrast because of different index forms of building standards and guidelines. In national index, the comprehensive energy consumption index per square meter and comprehensive energy consumption per person has been made. In Beijing, multiple forms have been classified, such as comprehensive universities, universities of science and technology, universities of literature and history, single university and other colleges and universities.

(2) Assessment measures: the standards made in Beijing, Anhui and Sichuan is similar to the national standards. It has been assessed from organization structure, system construction, planning design and energy-saving and environmental technology. Based on the scoring system combining qualitative and quantitative methods, the working achievements during the green campus construction have been assessed comprehensively.

(3) Technical guide rule of energy-auditing: relevant technical guidelines have been made and operable energy efficiency methods have been proposed for different depth of energy auditing in Shanghai to boost the energy-saving works of local school and guarantee the completion of energy-saving goal.

(4) Guide rule of energy-saving monitoring system construction: the guide rule of energy-saving monitoring system construction made in Shanghai is different from the national standards. Besides, 
more detailed rules have been made in building information and the collected content of subentry energy consumption and the chapter of operation maintenance and management have been added.

Table.2. the summary table local construction standards and guidelines

\begin{tabular}{c|c|c|c|c}
\hline \multicolumn{9}{c}{ ( - vacancy , Vestablished ) } \\
\hline Provinces & $\begin{array}{c}\text { The guide for energy } \\
\text { use }\end{array}$ & $\begin{array}{c}\text { Examination and } \\
\text { evaluation }\end{array}$ & Energy audit & $\begin{array}{c}\text { Energy-saving } \\
\text { regulatory system }\end{array}$ \\
\hline Shanghai & - & - & $\sqrt{ }$ & $\sqrt{ }$ \\
\hline Beijing & $\sqrt{ }$ & $\sqrt{ }$ & - & - \\
\hline Sichuan & $\sqrt{ }$ & $\sqrt{ }$ & - & - \\
\hline Anhui & - & - & - & - \\
\hline Guangxi & $\sqrt{ }$ & - & - & - \\
\hline Hunan & $\sqrt{ }$ & - & - & -
\end{tabular}

\section{Problem and reason analysis of the existing standards and guidelines}

\section{Problem Analysis}

(1) The green campus planning and the green design standards for campus buildings have not been made in China up to now. The energy-saving planning and green building design just refer to the relevant energy-saving design standards and codes made by China as well as refer to existing national regulations and standards. However, the technical measures of the energy saving and emission reduction of the campus buildings have not been proposed and the technical guidance has been not made based on the characteristics of campus.

(2) The current standards and technical guidelines are not comprehensive and systematic and its way of formulating is not scientific and the content is not specific. At present, the regional and different types of standards for energy and water in the buildings of colleges and universities have not been established. Besides, there are not unified standards for the energy and water consumption management and evaluation. In terms of the provinces where standards for water and energy consumption have been made, the index form and way of formulating are different, thus it is impossible to compare the energy consumption between the colleges and universities in different provinces and cities. Although relevant supporting policies and regulations have been made to some degree, the integrated system has not been formed and the energy-saving statistics, monitoring and assessment system is to be improved.

(3) Not good executive force. The colleges and universities have not emphasized it, students and teachers are not active. Besides, China has not incorporated the energy-saving requirements into the assessment index. Thus the resource-saving campus construction is lack of external drive and internal pressure, which leads to the bas execution of national and local policies and standards.

\section{Reason Analysis}

(1) The division of labor and cooperation are lack in central ministries and commissions; the local government fails to cooperate with the central government closely. In terms of the relevant policies issued now, the Ministry of Education and Housing and Urban-rural Construction Agency are main driving force. However, they neither combine the advantage of their own research direction, nor divided the work or cooperate. They just stay in the formulating of general requirement for the resource-saving campus construction.

(2) "Top-down" mode is lack of long-term operation effect. It is hard to establish a long-term and effective development mechanism for the organization mechanism of constructing the resource-saving campus are "top-down" mode from central government to local government and even to the internal management. 
(3) The current philosophy and way of schooling and the management mechanism is hard to meet the requirement of green campus construction in colleges and universities. They are just limited to the promotion of the idea of energy saving and emission reduction as well as the adoption of energy-saving management measures. Therefore, their recognition is insufficient and hard to meet the requirement of green campus construction.

(4) The investment is not enough, the financing gap in the construction of resource-saving campus is large and the financing channels are not multiple. Multiple financing channels for resource-saving campus construction have not been formed yet and it is hard to meet the requirement of resource-saving campus construction in numerous colleges and universities just depending on the financial support from national or local government.

\section{Suggestions of green campus's construction standards and guidelines}

(1) If the resource-saving campus is upgraded to the green campus construction, the guidelines should be supplemented in green education, green scientific research and green humanism. Its content shall be expanded to the green campus planning construction, ecological and energy saving reconstruction, healthy environment creation, low-carbon campus life advocacy, green education course setting and green human activity implementation. The current standards and guidelines should be supplemented correspondingly to promote the construction and development of green campus.

(2) In the aspect of technology, it should be focused on the collection of basic data and data sharing between the colleges and universities. Besides, the scientific method should be made based on it and the technical standards and guidelines should be made specifically based on the energy using characteristics of campus buildings. The useful information behind the numerous statistical data should be analyzed and extracted by way of data mining and artificial intelligence, thus guiding high-efficient and energy-saving work more scientifically.

(3) The executive force should be enlarged for the standards and guidelines. On one hand, national and local government should make some mandatory standards and determine the construction content that colleges and universities should meet to promote the adoption of the basic technology of green campus. On the other hand, corresponding supervision, assessment and rewarding system should be made actively.

\section{Acknowledgments}

This research was supported by Project in the National Science \& Technology Pillar Program during the Twelfth Five-year Plan Period (Project name: Evaluation and optimization of building energy consumption system \& Research and demonstration of self-insulation system, Project number: 2011BAJ03B11)

\section{References}

[1] H.W. TAN, S.Q. Chen, N. Zhang. etc. The annual report of China green university of (2011). China green university Union.Shanghai, Information on 2012.6.www.cgun.org.

[2] H.W. TAN. energy saving of Management, science technology and behavior , interpretation of construction management and technical guidance and institutions of the economical campus (trial)" [J]. Construction Science and Technology. 15 (2008)22-25.

[3] ULSF. Sustainability Assessment Questionnaire. University Leaders for a Sustainable Future,1999.

[4] J.T. Zhang. The study on The construction of a conservation-minded campus study economical campus construction in colleges and universities. Southwest university.2009. 